\title{
Red Blood Cell Size and Glycolytic Enzyme Activity: Relationship to Number of Intramedullary Cell Divisions
}

\author{
BERTIL E. GLADER, ${ }^{(11)}$ DANIEL MCCRIMMONS, AXIA MÜLLER-SOYANO, AND ORAH PLATT \\ Department of Pediatrics, Harvard Medical School, the Division of Hematology-Oncology, Children's Hospital \\ Medical Center, Boston, Massachusetts; and the Department of Pediatrics, Stanford University School of \\ Medicine, Stanford, California, USA
}

\begin{abstract}
Summary
In order to assess how the number of cell divisions influences the red blood cell (RBC) content of proteins other than hemoglobin, we measured the activity of two age-independent glycolytic enzymes in macrocytic, normal, and microcytic RBCs. The enzymes measured were phosphoglycerate kinase (PGK) and lactic dehydrogenase (LDH). In macrocytes, both PGK and LDH activity $/ 10^{10}$ RBCs were increased 1.6-fold over normal RBCs. In microcytes, however, the activity of these enzymes was identical to that seen in normal RBCs.

\section{Speculation}

These results are consistent with the hypothesis that macrocytes undergo fewer intramedullary cell divisions. Contrary to current concepts, however, the identical enzyme activity in normal and microcytic RBCs suggests that these cells have undergone the same number of cell divisions. The smaller volume of microcytes can be explained by decreased hemoglobin synthesis since it is known that the volume of growing cells is influenced by the cation and water accumulation which accompanies amino acid incorporation into protein.
\end{abstract}

It generally is held that developing RBCs are released from the bone marrow after the mean cell $\mathrm{Hb}$ concentration reaches a critical level $(1,7)$. Under conditions of severe anemic stress, elevated erythropoietin levels lead to the early release of fully hemoglobinized macrocytes which have skipped a terminal cell division $(1,6)$. In contrast, hemoglobin synthetic defects such as iron deficiency and thalassemia trait are characterized by microcytosis, presumably because these cells undergo an extra cell division before the critical mean cell $\mathrm{Hb}$ concentration is reached $(1,3)$. Thus, while the MCHC in different sized RBCs is relatively constant, the corpuscular hemoglobin $(\mathrm{MCH})$ content varies directly with cell size. The degree to which the erythrocyte content of other proteins also varies with cell volume is not known. In the studies reported here, we measured the activity of two glycolytic enzymes in RBCs with different mean corpuscular volumes (MCVs). The enzymes studied were PGK and LDH. Both of these are age-independent enzymes, and thus their activity in a population of RBCs accurately reflects the enzyme endowment of erythrocytes as they are released from the marrow (4).

\section{MATERIALS AND METHODS}

Blood was obtained from healthy normal blood donors and patients with RBCs of abnormal size. Macrocytic RBCs were obtained from the following patients (number of patients): aplastic anemia (two), Fanconi's hypoplastic anemia (three), congenital red cell hypoplasia (two), pernicious anemia (two), and normal cord blood (three). Microcytic RBCs were obtained from patients with $\beta$-thalassemia trait (nine) and iron deficiency (three). Blood was collected in EDTA and processed for assay within $2 \mathrm{hr}$ of collection. RBC counts, hemoglobin concentration, and $\mathrm{MCH}$ were determined in a Coulter model-S electronic counter. Hematocrit was measured in an International microcentrifuge, and the MCV calculated from the Coulter RBC count and manual hematocrit $(\mathrm{MCV}=$ hematocrit $\times 10 /$ $\left.\mathrm{RBC} \times 10^{6}\right)$. Young and old RBC fractions were obtained by sedimenting washed RBCs (45 min, $1000 \times g$ room temperature) in a tabletop centrifuge (Sero-fuge, Clay-Adams, Parsippany, NJ) and then removing the top tenth (young) and bottom tenth (old) of the cell column. Preparation of hemolysates and measurement of PGK, LDH, and glucose-6-phosphate dehydrogenase (G6PD) were done according to the method of Beutler (2) except that the assays were performed at $25^{\circ}$. Enzyme results were calculated on the basis of cell number (enzyme units/10 RBCs).

\section{RESULTS}

\section{ENZYME ACTIVITY IN YOUNG AND OLD ERYTHROCYTES}

G6PD, PGK, and LDH were assayed in young and old red blood cells (Table 1). The activity of G6PD, which is known to be an age-dependent enzyme, was increased in young RBCs but there were no age-related changes in PGK and LDH. These data confirm previous findings that PGK and LDH activity are relatively independent of RBC age (4).

\section{ENZYME ACTIVITY IN MACROCYTIC, NORMOCYTIC, AND} MICROCYTIC RBCS

Compared to normal RBCs, macrocytes contain more hemoglobin (increased $\mathrm{MCH}$ ) and also have 1.6-fold more PGK and LDH activity per cell (Table 2). On the other hand, microcytic RBCs contain less hemoglobin per cell (decreased $\mathrm{MCH}$ ), although the activity of PGK and LDH is the same as in normocytic cells (Table 2).

Table 1. Reticulocytes (percentage) and enzyme activity (EU/ $10^{10} R B C$ ) assessed in top and bottom layers of control RBCs after centrifugation for $45 \mathrm{~min}^{1}$

\begin{tabular}{lrr}
\hline & \multicolumn{1}{c}{ Top } & \multicolumn{1}{c}{ Bottom } \\
\hline Reticulocytes (\%) & $8.4 \pm 0.7$ & $0.7 \pm 0.4$ \\
G6PD (EU $/ 10^{10}$ RBC) & $3.2 \pm 0.4$ & $1.8 \pm 0.1$ \\
PGK (EU/1010 RBC) & $27.9 \pm 2.3$ & $25.3 \pm 0.6$ \\
LDH (EU/10 $10^{10}$ RBC) & $39.4 \pm 3.2$ & $35.8 \pm 2.0$ \\
\hline
\end{tabular}

\footnotetext{
${ }^{1}$ Results are mean \pm SD of five separate samples of blood.
} 
Table 2. Enzyme activity (EU/10 $\left.{ }^{10} R B C\right)$ assayed in macrocytic, normocytic, and microcytic $R B C \boldsymbol{s}^{1}$

\begin{tabular}{lrrr}
\hline & Macrocytes & $\begin{array}{c}\text { Normo- } \\
\text { cytes }\end{array}$ & Microcytes \\
\hline MCV $\left(\mu^{3}\right)$ & $111 \pm 7.1$ & $91 \pm 1.6$ & $64 \pm 5.2$ \\
MCH $(\mathrm{ng})$ & $37 \pm 1.9$ & $31 \pm 1.1$ & $20 \pm 2.2$ \\
PGK $\left(\mathrm{EU} / 10^{10} \mathrm{RBC}\right)$ & $42.0 \pm 6.7$ & $27.0 \pm 1.7$ & $25.8 \pm 4.1$ \\
LDH (EU $\left./ 10^{10} \mathrm{RBC}\right)$ & $59.7 \pm 9.7$ & $37.1 \pm 5.9$ & $37.3 \pm 5.7$ \\
No. of samples & 12 & 15 & 15 \\
\hline
\end{tabular}

${ }^{1}$ Results are expressed as mean $\pm S D$.

\section{DISCUSSION}

$\mathrm{MCH}$ varies directly with $\mathrm{RBC}$ size, and this is thought to reflect the number of intramedullary cell divisions (macrocytes $<$ normocytes $<$ microcytes) $(1,3,7)$. In order to assess how the number of cell divisions influence the content of other RBC proteins, we measured the activity of two age-independent glycolytic enzymes in different sized RBCs. In macrocytes, the parallel increases are consistent with the concept that large RBCs undergo fewer cell divisions than normal erythrocytes. In microcytes, however, the $\mathrm{MCH}$ is significantly lower than normal, whereas enzyme activity is isentical to that in normocytic cells. These data are more difficult to explain.

The currently accepted hypothesis is that microcytes undergo a greater than normal number of cell divisions and consequently these cells are smaller (decreased MCV) and contain less hemoglobin (decreased $\mathrm{MCH}$ ). If this concept is correct, it also is necessary to postulate that enzyme synthesis persists during the prolonged intramedullary maturation of micronormoblasts. Our studies with normal and macrocytic RBCs, however, indicate that cell division produces a decrement in enzyme activity of daughter cells. Thus, if microcytes undergo additional cell divisions, it is unclear why a further reduction in enzyme content of these cells is not observed.

As an alternative explanation for these enzyme data, we propose that microcytic RBCs undergo a normal number of intramedullary divisions. The differences in cell size can be explained by impaired hemoglobin synthesis and decreased amino acid uptake. It is well established that amino acid transport into cells is largely dependent on a carrier-mediated process which simultaneously moves $\mathrm{Na}$ into cells (5). In growing cells that are synthesizing protein, this "cotransport" system is responsible for significant $\mathrm{Na}$ influx as well as amino acid incorporation. Since most cells have an active $\mathrm{Na}-\mathrm{K}$ transport system, however, $\mathrm{Na}$ which enters cells is rapidly extruded in exchange for $\mathrm{K}$. Thus, the net effect of amino acid incorporation is an elevated $\mathrm{K}$ content, and this leads to increased intracellular osmolality, water influx, and hence an increased cell volume. Conversely, decreased amino acid incorporation into growing cells will result in a correspondingly smaller cell volume increase. Thus, the small size of microcytes can be explained by decreased hemoglobin synthesis and reduced cellular hydration. There is no compelling reason to invoke additional cell divisions.

\section{CONCLUSION}

Hemoglobin content and activity of two age-independent glycolytic enzymes were measured in different-sized RBCs. In large RBCs (macrocytes), both hemoglobin content and enzyme activity were greater than control RBCs (normocytes). In contrast, small RBCs (microcytes) contained an identical amount of enzyme activity although their hemoglobin content was significantly reduced.

\section{REFERENCES AND NOTES}

1. Beck, W. S.: Hematology, Ed. 2, p. 127 (The MIT Press, Cambridge, MA) 2. Beutler, E.: A Manual of Biochemical Methods (Grune \& Stratton, New York, 1971).

3. Levanthal, B., and Stohlman, F., Jr.: Regulation of erythropoiesis. XVII. The determinants of red cell size in iron-deficiency states. Pediatrics, 37: 62 (1966).

4. Oski, F.: Red cell metabolism in the newborn infant. V. Glycolytic intermediates and glycolytic enzymes. Pediatrics, 44: 84 (1969).

5. Schultz, S. G., and Curran, P. F.: Coupled transport of sodium and organic solutes. Physiol. Rev., 50: 637 (1970).

6. Stohlman, F., Jr.: Observations on the kinetics of red cell proliferation. In: F. Stohlman, Jr.: The Kinetics of Cellular Proliferation, p. 318 (Grune \& Stratton, New York, 1959).

7. Stohlman, F., Jr., Howard, D., and Beland, A.: Humoral regulation of erythropoiesis. XII. Effect of erythropoietin and iron on cell size in irondeficiency anemia. Proc. Soc. Exp. Biol. Med., 113: 986 (1963).

8. We wish to thank Miss Margaret Macksey for her excellent technical assistance and Dr. David G. Nathan for his helpful advice.

9. The research purpose of this study was explained to all patients and/or their parents or guardian.

10. Dr. Glader is a recipient of a Research Career Development Award (AM00435 ) from the NIH. This research was supported by USPHS Grants AM05581 and $A M-15322$.

11. Requests for reprints should be addressed to: Dr. Bertil E. Glader, M.D., Department of Pediatrics, Stanford University School of Medicine, Stanford, CA 94305 (USA).

12. Received for publication May 19,1977

13. Accepted for publication July $27,1977$. 